Yüzüncü Yil Üniversitesi
Tarim Bilimleri Dergisi
(YYUJournal of AgriculturalScience)
http://dergipark.gov.tr/yyutbd

Araştırma Makalesi (ResearchArticle)

\title{
Peyniraltı Suyuyla Zenginleştirilmiş Fermente Süt İçeceği Üretimi**
}

\author{
Şule Nur D. SAÇKESEN ${ }^{1}$, Elvan OCAK ${ }^{* 2}$ \\ ${ }^{1}$ Karaman İl Tarım ve Orman Müdürlüğü, Karaman, 70100, Karaman, Türkiye \\ ${ }^{* 2}$ Yüzüncü Y1l Üniversitesi, Mühendislik Fakültesi, G1da Mühendisliği Bölümü, 65080,Van, Türkiye \\ *Sorumlu yazar e-posta:elvanocak@yyu.edu.tr
}

\section{Makale Bilgileri}

Geliş: 23.11.2018

Kabul: 08.05.2019

Online Yayınlanma 28.06.2019

DOI: 10.29133 /yyutbd.486896

Anahtar kelimeler

Depolama,

Duyusal özellikler,

Fermente içecek,

Peyniraltı suyu
Öz:Bu çalışmada, farklı miktarlarda peyniraltı suyu ilave edilerek üretilen fermente süt içeceklerinin depolama süresi boyunca bazı fiziksel, kimyasal ve duyusal özellikleri araştırılmıştır. Yoğurda farklı oranlarda peyniraltı suyu ve su ilave edilerek üretilen içecekler, 7 gün boyunca $4^{\circ} \mathrm{C}$ 'de depolanmıştır. Analiz sonuçlarına göre; örneklerin ortalama $\mathrm{pH}$ değerleri 3.66-4.11, titrasyon asitliği değerleri (laktik asit cinsinden) 0.58-0.71, kurumadde oranları \%5.33-7.21, protein oranları $\% 0.27-0.30$, kül oranları $\% 0.60-1.11$, serum ayrılması değerleri 2-19 (ml/100 mL), viskozite değerleri 3-5 cP, yağ oranları \%1-1.3 arasında tespit edilmiştir. Depolama süresince içeceklerin $\mathrm{pH}$ ve viskozite değerleri genel olarak azalmış; titrasyon asitliği, kül oranları ve serum ayrılması değerleri artış göstermiş; kurumadde, azot ve yağ oranları değerlerinde önemli değişiklikler meydana gelmemiştir.

\section{Production of Fermented Milk Drinks Enriched with Whey}

\section{ArticleInfo}

Recieved: 23.11.2018

Accepted: 08.05.2019

Online Published28.06.2019

DOI:10.29133/yyutbd.486896

\section{Keywords}

Storage,

Sensory properties,

Fermented beverages,

Whey

\begin{abstract}
In this study, by adding different amounts of whey produced during the storage time of some physical fermented milk beverage, chemical and sensory properties were evaluated. Different ratios of whey and yoghurt drinks by adding water produced was stored at $4^{\circ} \mathrm{C}$ for 7 days. According to the results; the $\mathrm{pH}$ values of the samples 3.66-4.11, 0.58-0.71 titratable acidity values, \% of dry matter content of 5:33 to 7:21, 0:27 to 00:30\% nitrogen ratios, ash content 0.60$1.11 \%$, whey separation values from 2 to $19(\mathrm{ml} / 100 \mathrm{ml}) 3-5$ cPviscosity, oil ratios (1-1.3\%) were detected between. $\mathrm{pH}$ and viscosity values of the beverage during storage may be generally reduced; titratable acidity, ash and serum separation value has increased; dry matter, nitrogen and oil ratios significant change in value has occurred.
\end{abstract}

${ }^{* *}$ Çalışma tezden üretilmiştir.

1. Giriş

İçme sütüne gereken değer verilmeyen ülkemizde süt çeşitli mamüllere işlenerek tüketilmekte; böyle olunca da sütte bulunan önemli besin maddelerinin büyük bir kısmı süt artığı olarak nitelendirilen peyniraltı suyu, yayık altı, haşlama suyu gibi yan ürünlere geçmektedir. Süt teknolojisinin en önemli yan ürünlerinden biri olan peyniraltı suyu; sütün peynir mayası veya organik asitle pıhtılaştırılmasından ve peynirin esasını oluşturan pıhtının tam yağlı ya da yağsız sütten ayrılmasından sonra, geriye kalan yeşilimsi sarı renkteki sıvı protein kaynağı olarak adlandırılmaktadır 
ve değerlendirilmediği takdirde çevre kirliliğine sebep olmaktadır. Son zamanlarda teknolojinin gelişmesi ve insanların fonksiyonel gıdalara yönelmesine paralel olarak peyniraltı suyundan elde edilecek ürünlerin çeşitliliği arttırılabilir ve her zevke hitap edebilen ürünler piyasaya sunulabilir. Böylece bu ürünlerin ülkemizdeki tüketilme miktarı arttırılabilir; insan sağlığına özellikle de çocukların gelişimine önemli düzeyde katkı sağlanabilir (Bakırcı ve Kavaz, 2006;Dağlı 2006; Burucu, 2008;Yerlikaya ve ark., 2010;Özaltın, 2011; Özcan ve Delikanl1, 2011; Dinçoğlu ve Ardıç, 2012).

Bileşim olarak sütle benzerlik gösteren peyniraltı suyu süt kuru maddesinin yaklaşık yarısını, süt şekerinin neredeyse tamamını, proteinlerin yaklaşı $1 / 5$ 'ini ve $B$ vitaminlerinin ise büyük bir bölümünü içermektedir. Peyniraltı suyunun besin değerini içerdiği kalsiyum, fosfor, laktoz ve serum proteinleri artırmaktadır (Alpkent ve Göncü, 2003). Peyniraltı suyu sütte bulunan hemen hemen tüm çözünür tuzları ve mikro elementleri içerebilmektedir. Miktarları peynir üretim teknolojisine bağlı olarak değişen mineraller peyniraltı suyu kuru maddesinin yaklaşık \%7-12'lik bir kısmını oluşturmaktadır (Jeličić ve ark., 2008).

Günümüzde tüketiciler besin tercihlerini hastalıkların oluşumunu azaltan, koruyan, tedavi eden ve aynı zamanda vücudun temel besin öğelerini karşılayan gıdalardan yana kullanmaktadırlar. Yapılan invitro çalışmalar ve hayvan deneyleri peyniraltı suyu proteinlerinin besleyici özelliklerinin yanında antikarsinojenik, antiviral, hipokolestrolemik vb. etkilerinin de olduğunu göstermiş̧tir (Karagözlü ve Bayarer, 2004). Peyniraltı suyu proteinlerinin ve aminoasitlerinin besleyici nitelikleri ve hastalıkları önleyici/tedavi edici etkilerinin bilimsel olarak ortaya koyulmaya başlanmasıyla günümüzde üretilen ve gelecekte üretilecek yeni nesil ürünlerin formülasyonunda vazgeçilmez bir girdi olacağ 1 açıkça görülmektedir (Özaltın, 2011). Bu nedenle bu çalışmada; yoğurda belli miktarlarda su ve peyniraltı suyu ilave edilerek üretilen fermente süt içeceği ile besleyici değerinin arttırılması, işlenmeden doğaya atılan peyniraltı suyundan kaynaklanan çevre kirliliğinin bir miktar da olsa önüne geçilmesi ve hiçbir işleme tabi tutulmadan kullanılan peyniraltı suyundan ekonomik kazanç sağlanması amaçlanmaktadır.

Peyniraltı suyunun içecek olarak kullanımı antik Yunan çağına kadar uzanmaktadır. M.Ö. 460'da Hipokrat çeşitli hastalıkların tedavisinde kullanılmak amacıyla peyniraltı suyunun kullanımını tavsiye etmiştir. XIX. yüzyılın ortalarında Batı Avrupa'da peyniraltı suyu ile tedavi şekli yaygınlaşarak 400'ün üzerinde tedavi evi açılmış; 1940'lı yılların sonlarına gelindiğinde ise Orta Avrupa'da hazımsızlık, romatizma, gut, anemi, karaciğer rahatsızlıkları ve hatta tüberkülozun tedavisinde dahi günde 1500 gr peyniraltı suyu tüketilmesi uygun görülmüştür (Holsinger ve ark., 1989).

Ülkemizde pek bilinmemekle birlikte peynir suyundan değişik içecekler elde edilmektedir. Peynir suyuna çeşitli meyve aromalarının farklı oranlarda ilave edilmesiyle değişik isimler altında üretilen alkolsüz içeceklerde kayısı, şeftali, mango, turuçgiller, elma, muz ve üzüm gibi meyveler kullanılmaktadır (Alpkent ve Göncü, 2003). Peyniraltı suyuna \%10 elma/limon suyu ilave edilmesiyle elde edilen Fruisghurt; PAS, mango suyu ve Bifidobacteriumkültüründen oluşan Mango-molkemix; Vitamin E ile aromalandırılmışpeyniraltı suyu olan Big M; peyniraltı suyu, kayısı, elma suyu gibi çeşitli tipte sağlığa yararlı gıdalar ihtiva eden Frucht-molke (Heirler); peyniraltı suyu, \%15 siyah üzüm suyu ya da \%25 karışı meyve suyu içeren Frucht-molke (Immensee); \%35 berrak deproteinizepeyniraltı suyu ve su karışımından oluşan Rivella ve buna benzer özellikler gösteren Surella; yağsız yoğurt (\%44), peyniraltı suyu (\%45) ve çilek suyu (\%1) içeren Interlac; \%80 peyniraltı suyu, \%12.8 meyve suyu konsantratı ve tatlandırıcı içerikli Djoez; \%85.3 peyniraltı suyu ve renklendirilmiş tropikal meyve suyu (\%6.3) karışımından oluşan Taksi; yağsız yoğurt (\%46.4), peyniraltı suyu (\%43) ve çilek, kiraz, elma gibi meyvelerin sularından oluşan Yor; \%70 fermente olmuş PAS, \%15 yağsız süt ve \%15 tatlandırılmış meyve suyu karışımından oluşan Yoghurt-turmix önemli peyniraltı suyu içeceklerindendir (Kırdar,2001).

Peyniraltı suyu bira benzeri alkollü içeceklerin yapımı için oldukça elverişli bir hammaddedir. Deproteinize asit peyniraltı suyuna sakkaroz ve karamelize şeker, bira mayası, meyve aroması ve su ilavesinden sonra oluşan karışımın şişelenip $18^{\circ} \mathrm{C}^{\prime}$ de $8-12$ saat fermentasyona bırakılmasıyla peynir suyu şampanyası üretilmektedir (Holsinger ve ark.,1989). Peyniraltı suyunun kefir kültürüyle fermente edilmesiyle elde edilen milone \%0.8 oranında alkol içeren ve $\mathrm{CO}_{2}$ gazı verilerek şişelenen bir peyniraltı suyu içeceğidir. Polonya' da elde edilen serwoit denilen peyniraltı suyu köpüklü şarabı da bu kategoridedir (Alpkent ve Göncü, 2003; Dinçoğlu ve Ardıç, 2012). 
Çalışmamızda birçok çalışmadan farklı olarak peyniraltı suyu direkt olarak ürüne katılmıştır. Böylelikle başka bir fraksiyona dönüşüm için gerekli olan maddi kayıp ve insan gücü kaybının önüne geçilerek; besleyici değeri yüksek ekonomik bir ürün elde etmek amaçlanmıştır.

\section{Materyal ve Yöntem}

Araştırma materyalimizin esasını yoğurt, peyniraltı suyu ve su oluşturmuştur. Peyniraltı suyu Van Yüzüncü Y1l Üniversitesi Mühendislik Fakültesi G1da Mühendisliği Süt Teknolojisi Laboratuarı'nda maya ile pıhtılaştırılmış Beyaz peynir üretimi sonucu elde edilmiştir. Araştırmada; Dalpa Gıda Yemek Temizlik İnş. Paz. ve Tic. San. Ltd. Şti.'nin üreterek piyasaya sunmuş olduğu Sütkur markalı vakumlu yoğurdu ve Karivan A.Ş. tarafindan üretilerek piyasaya sunulan Binpınar markalı doğal kaynak suyu kullanılmıştır. Peyniraltı suyu ile zenginleştirilmiş fermente süt içecekleri için 200 ml'lik polipropilen ambalajlar tercih edilmiştir.

Çizelge 1. Üretimde kullanılan peyniraltı suyunun bileşimi

\begin{tabular}{ll}
\hline Bileşimi & Miktarı \\
\hline Kuru madde (\%) & 7.85 \\
Yă̆ (\%) & 0.5 \\
Asitlik (\% laktik asit) & 0.11 \\
pH & 6.74 \\
Protein (\% kuru madde) & 10.72 \\
Kül (\%) & 0.5 \\
\hline
\end{tabular}

Çizelge 2. Üretimde kullanılan yoğurdun bileşimi

\begin{tabular}{ll}
\hline Bileşimi & Miktarı \\
\hline Kuru madde (\%) & 10.22 \\
Yağ (\%) & 2.0 \\
Asitlik (\% laktik asit) & 0.64 \\
$\mathrm{pH}$ & 3.98 \\
Protein (\%) & 3.47 \\
Kül (\%) & 0.69 \\
\hline
\end{tabular}

Peyniraltı suyu ile zenginleştirilmiş fermente süt içeceği üretimi için ön deneme yapılmıştır. Yoğurda farklı oranlarda peyniraltı suyu ve su ilavesi yapılarak bir fermente süt içeceği hazırlanmıştır. Asıl denemede "Çizelge 3." 'te belirtildiği gibi bir deneme planı uygulanmıştır. Bu plana göre; satın alınan yoğurda, yoğurtla eşit miktarda, her bir grup için ön denemede belirlenen oranlarda su ve pastörize peyniraltı suyu (55 $\square$ C'de $15-20$ dakika 1 sıl işleme tabi tutulduktan sonra $20^{\circ} C^{\prime}$ ye kadar soğutulmuş) ilave edilerek fermente süt içecekleri hazırlanmıştır. Sonra örneklere \% 0.5 oranında tuz ilave edilerek örnekler $200 \mathrm{~kg} / \mathrm{cm}^{2}$ basınçta homojenize edilmiş ve kapalı sistem ambalajlama makinasında 200 ml'lik polipropilen plastik bardaklara doldurularak paketlenmiştir. Daha sonra $+4^{\circ} \mathrm{C}$ 'de 7 gün süreyle depolanarak; depolamanın 1. ve 7. günlerinde kimyasal, fiziksel ve duyusal özellikleri test edilmiştir. Analizler paralelli olarak yürütülmüştür. İstatistiksel analizler Tesadüf Parselleri Deneme Planı’na göre SPSS 10.0 paket programı kullanılarak yapılmıştır.

Çizelge 3. Deneme Planı

\begin{tabular}{ll}
\hline Örnekler & İlave edilen PAS ve su miktarları \\
\hline Kontrol & $\% 0$ PAS + \%100 su \\
A & $\% 5$ PAS + \%95 su \\
B & $\% 10$ PAS + \%90 su \\
C & $\% 25$ PAS + \%75 su \\
D & $\% 40$ PAS + \%60 su \\
\hline
\end{tabular}


Kuru madde ve toplam protein tayini AOAC (1990)'a göre; pH değeri Kosikowski (1982)'ye göre; yağ, laktik asit cinsinden asitlik oranı ve kül değeri Kurt ve ark. (2003)'e göre belirlenmiştir. Serum ayrılması değeri Köksoy ve Kılıç (2004)'e göre; Renk değeri Doğan (2002)'ye göre belirlenmiştir. HPScanJet G2410 tarayıcı ile taranan içecekler, HP Precision Scan LT programı ile analiz edildikten sonra PSG resim formatında saklanmıştır. Saklanan görüntüler "LabColorMod" (16 Bits/channel) ayarları kullanılarak $L, a, b$ değerleri belirlenmiştir. 0-255 arasında ifade edilen $L, a, b$ değerleri standart renk ölçerde belirtildiği gibi, $\mathrm{L}=0-100,+a=0-60, \quad+b=0-60$ olacak şekilde dönüştürülmüştür. Brookfield Viskozimetresi (Model DV-III Brookfield Engineering Laboratories, Inc., MA, ABD) kullanılarak örneklerin viskozite ölçümleri yapılmıştır. Bu amaçla homojen hale getirilen peyniraltı suyu ile zenginleştirilmiş fermente süt içecekleri $4{ }^{\circ} \mathrm{C}$ 'lik depolamanın ardından reometre kaplarına aktarılmıştır. Analizde 21 nolu başlık kullanılarak sonuçlar cP (mPa.s) olarak ifade edilmiştir. Peyniraltı suyu ile zenginleştirilmiş fermente süt içeceklerinin duyusal analizi, bu konuda belirli bir seviyede tecrübesi olan ve kendilerine daha önceden ön bilgiler verilmiş, 8-10 kişilik laboratuvar tipi panel grubunca yapılmıştır. Panelistler ürünün üzerlerinde bıraktığı etkiye göre görünüş, yapı-kıvam, tat-aroma, renk, koku ve genel değerlendirme yönünden 0-10 arasındaki skalada değerlendirme yapmıştır. Puanlama çok çok kötü (0), ne iyi ne kötü (5), çok çok iyi (10) seklinde olmuştur.
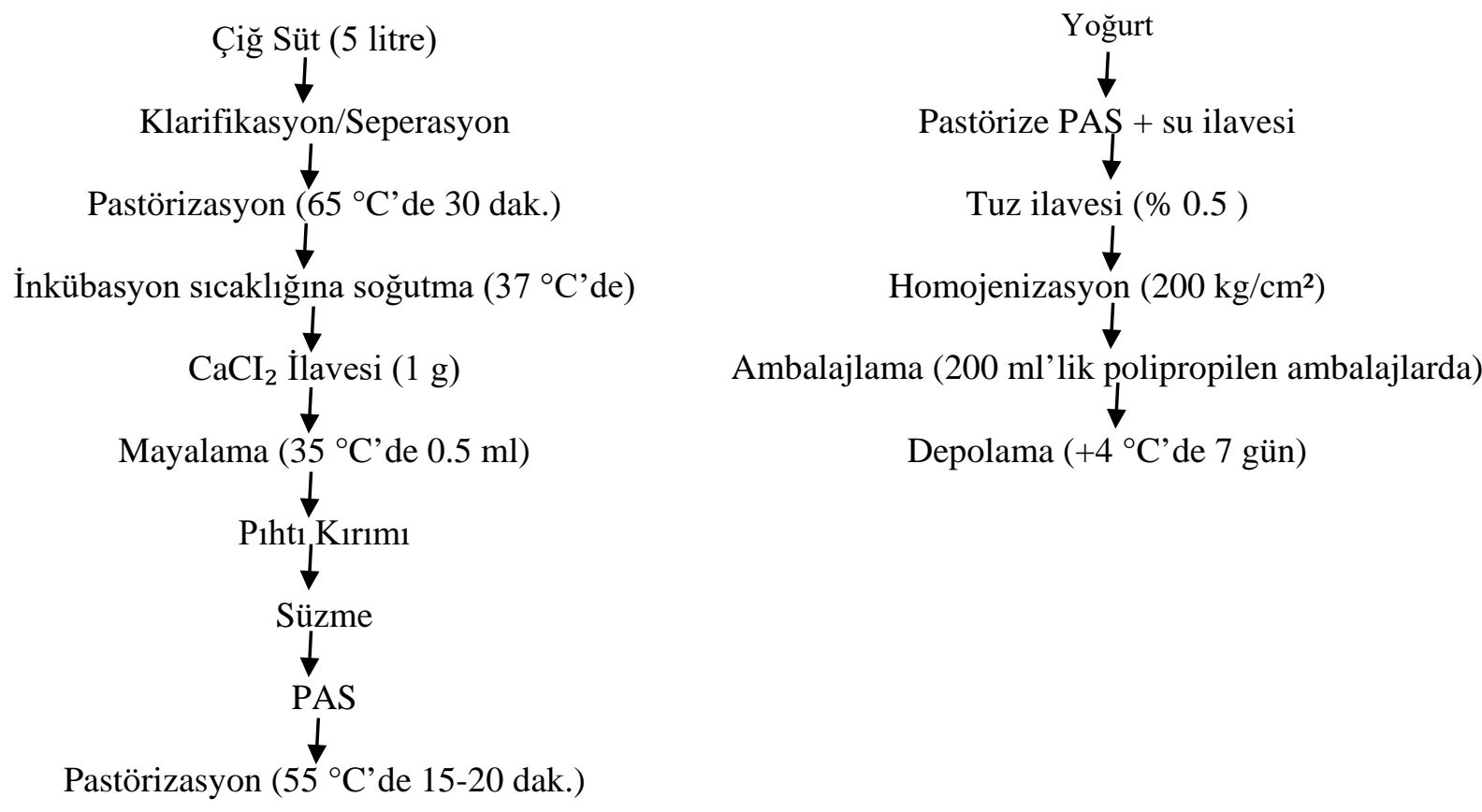

Şekil 1.Peyniraltı suyu eldesi ve peyniraltı suyuyla zenginleştirilmiş fermente süt içeceği üretimi.

\section{Bulgular}

Kuru madde, süt ve süt ürünlerinin istenilen fiziksel ve duyusal özelliklerinin elde edilmesinde önemli bir parametredir. Yapılan bilimsel çalışmalarda kuru madde içeriği ve miktarının ürünlerin fiziksel, kimyasal, mikrobiyolojik ve duyusal özelliklerini önemli ölçüde etkilediği görülmüştür. 7 günlük depolamada genel olarak ürünlerin kuru madde oranlarında bir değişiklik gözlemlenmemiştir. Ancak gruplar arasındaki kuru madde oranlarının farklılık göstermesi istatistiki olarak önemli bulunmuştur $(\mathrm{p}<0.05)$. Literatürde de fermente süt içeceklerinin kuru madde miktarını belirleyen çalışmalar mevcuttur. Esmek (2014)'in \%2 kefir kültürü, \%25 peyniraltı suyu ve \%75 süt kullanarak 3 farklı inkübasyon süresine $(24 \mathrm{~h}, 48 \mathrm{~h}, 72 \mathrm{~h})$ tabi tutarak içecek ürettiği çalışmasında 21 günlük depolama süresince içeceklerin kuru madde değerlerinde istatistiki olarak önemli bir değişiklik meydana gelmemiştir. Çalışmamızda kuru madde değerinin literatürdeki diğer çalışmalarda bulunan kuru madde değerine göre düşük çıkması; yoğurdun 1:1 oranında sulandırılmasından, düşük 
pastörizasyon sıcaklığı uygulamasından ve düşük kuru maddeli hammadde kullanımından kaynaklandığı düşünülmektedir.

Sütün önemli bir bileşeni olarak bilinen süt yağı; ekonomik değerinin dışında süt ve süt ürünlerinde tat-aroma gibi tekstürel özellikleri de etkilemektedir. Örneklerin yağ oranı değerleri \%1.0 ile \%1.30 arasında değişiklik göstermiştir. Yılmaz (2006)'ın yoğurt benzeri fermente süt ürünleri üretimi ile ilgili olarak farklı probiyotik kültür kombinasyonlarının kullanımını araştırdığı çalışmasında örneklerin yağ değerleri ortalaması 4.24 ile 4.43 arasında değişmiştir. Çalışmamızda kullanılan yoğurdun düşük yağ içermesi nedeniyle düşük yağ içerikli içecekler üretilmiştir. 16 Şubat 2009 tarih ve 27143 Sayılı Resmi Gazete'de yayımlanarak yürürlüğe giren Türk Gida Kodeksi Fermente Süt Ürünleri Tebliği'nde (2009/25) fermente süt ürünlerinin içereceği yağ oranı ağırlıkça en fazla \%10 olarak bildirilirken herhangi bir alt limit belirlenmemiştir. Peyniraltı suyu ile zenginleştirilmiş fermente süt içeceklerine ait kimyasal analiz sonuçları "Çizelge 4.' te gösterilmiştir.

Çizelge 4.Peyniraltı suyu ile zenginleştirilmiş fermente süt içeceklerine ait kimyasal analiz sonuçları

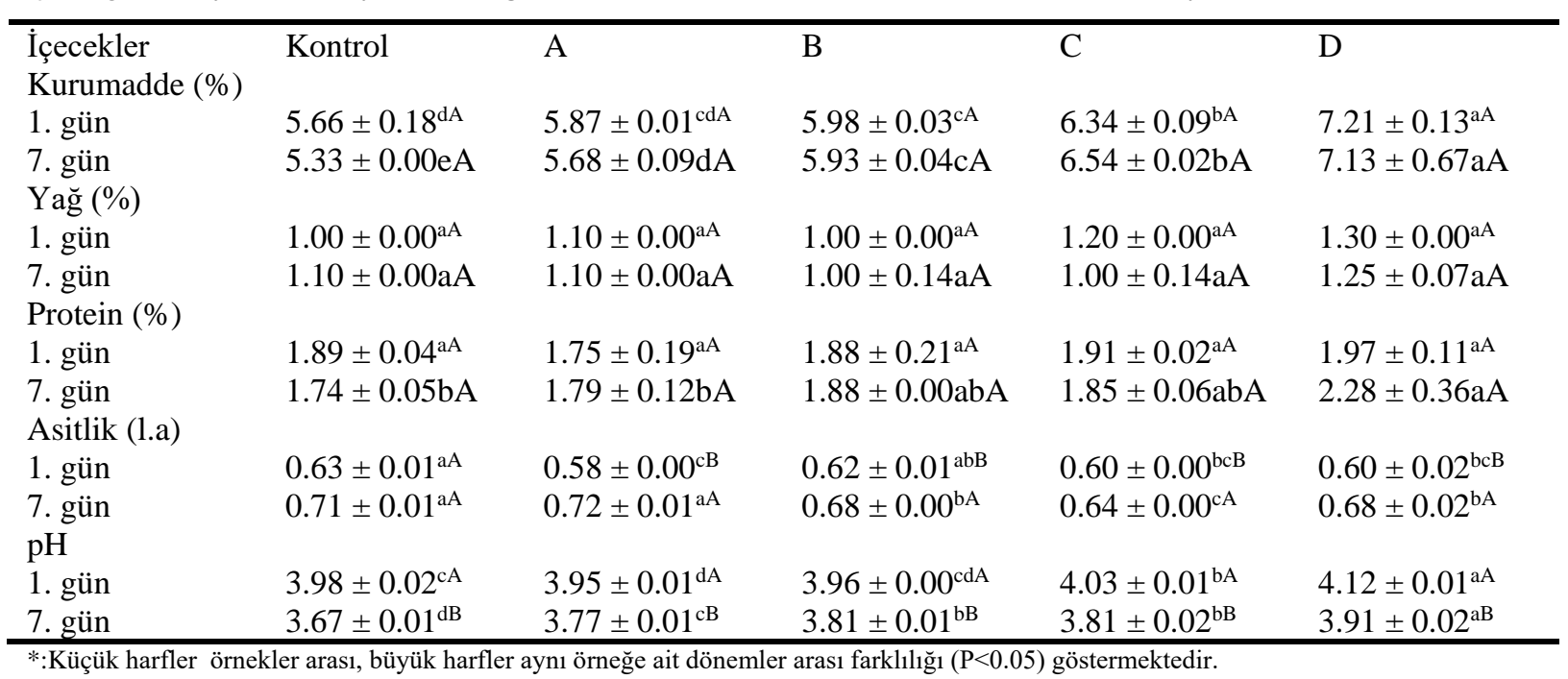

Sütün en önemli besin öğesi olan ve süt kuru maddesinin yaklaşık \%27’lik kısmını oluşturan süt proteinleri gıdalara; çözünme, viskoziteyi değiştirme, jelleşme, yapı-tekstür oluşturma, köpürme, emülsifiye etme, tat-koku bağlama gibi bazı fizikokimyasal özelliklerin kazandırılmasında etkilidirler. Depolama süresince en yüksek protein oranına depolamanın 7. gününde D içeceği (\%0.35), en düşük protein oranına ise yine depolamanın 7. gününde Kontrol içeceği $(\% 0.27)$ sahip olmuştur. Genel olarak içerdiği peyniraltı suyu miktarının artmasıyla içeceklerin protein miktarında da artış gözlenmiştir. Depolama süresinin içeceklerin protein miktarı üzerine etkisi istatistiki olarak önemli bulunmamıştır ( $>0.05$ ). Ferliarslan (2013), \%0.5, \%1 ve \%2 oranında inülin ve yulaf lifi ilave ederek kayısılı probiyotik fermente süt içeceği üretimi yaptığı çalışmasında içeceklerin protein değerlerini 0.46 ile 0.50 arasında bulmuştur. Çalışmamızda literatüre oranla daha düşük protein değerlerinin bulunma sebebinin; düşük protein ve kuru madde oranlı bir yoğurttan içecek üretilmesi olduğu düşünülmektedir.

Fermente süt ürünlerinin kendine has özelliklerinin oluşmasında laktik asit fermentasyonu büyük önem taşımaktadır. Ürünün asitlik derecesi ürünün yapısında ve serum ayrılmasında önemli bir etkendir. Depolama süresi boyunca içeceklerin asitlik değerinde genel olarak bir artış gözlemlenmiş ve bu artış istatistiki olarak önemli bulunmuştur $(\mathrm{p}<0.05)$. Literatürde fermente süt içeceklerinin titrasyon asitliği değerlerini Balcığlu (2013), \%0.49-\%0.70; Yılmaz (2006), \%1.28-1.73; Esmek (2014), \%0.7\%0.8 arasında bulmuştur. Türk Gıda Kodeksi Fermente Süt Ürünleri Tebliği'nde (2009/25) fermente süt ürünlerinin asitlik değeri en az \%0.3 olarak belirlenmiştir. Bu nedenle içecekler asitlik yönünden kodekse uygun bulunmuştur.

En yüksek kül değerine depolamanın 7. gününde D içeceği (1.11), en düşük kül değerine ise depolamanın 1. gününde Kontrol içeceği (0.60) sahip olmuştur. Hem gruplar arasındaki farklılık, hem de içeceklerin kül değerlerinin depolama süresi boyunca artış göstermesi istatistiki açıdan önemli bulunmuştur $(\mathrm{p}<0.05)$. Dane ve liyofilize kefir kültürü kullanılarak süt ve peyniraltı suyundan üretilen 
fermente süt içeceklerinin fiziksel, kimyasal, mikrobiyolojik ve duyusal özelliklerinin depolama süresince değişiminin araştırıldığı çalışmada ürünlerin kül değerleri $\% 0.47$ ile 0.53 arasında bulunmuştur (Şen, 2015). Çalışmamızda kül oranın düşük olması kuru madde oranı düşük yoğurt kullanılmasına bağlanabilir. Peyniraltı suyu ile zenginleştirilmiş fermente süt içeceklerine ait fiziksel analiz sonuçları ''Çizelge 5.'’te gösterilmiştir.

Çizelge 5. Peyniraltı suyuyla zenginleştirilmiş fermente süt içeceklerinin fiziksel analiz sonuçları

\begin{tabular}{llllll}
\hline İcecekler & Kontrol & $\mathrm{A}$ & $\mathrm{B}$ & $\mathrm{C}$ & $\mathrm{D}$ \\
\hline Viskozite (cP) & $4.90 \pm 0.14^{\mathrm{aA}}$ & $4.05 \pm 0.07^{\mathrm{bA}}$ & $4.85 \pm 0.07^{\mathrm{aA}}$ & $4.00 \pm 0.00^{\mathrm{bA}}$ & $4.70 \pm 0.14^{\mathrm{aA}}$ \\
1. gün & $3.85 \pm 0.21^{\mathrm{aB}}$ & $3.95 \pm 0.07^{\mathrm{aA}}$ & $3.05 \pm 0.07^{\mathrm{bB}}$ & $3.05 \pm 0.07^{\mathrm{bB}}$ & $3.30 \pm 0.14^{\mathrm{bB}}$ \\
7. gün & $2.000^{\mathrm{aA}}$ & $3.00 \pm 0.00^{\mathrm{aA}}$ & $3.00 \pm 0.00^{\mathrm{aA}}$ & $2.00 \pm 0.00^{\mathrm{aA}}$ \\
Serum ayr1lmas1 & $2.00 \pm 0.00^{\mathrm{aA}}$ & $3.00 \pm 0.00^{\mathrm{a}}$ & $11.00 \pm 4.24^{\mathrm{aB}}$ & $11.50 \pm 4.95^{\mathrm{aA}}$ & $8.00 \pm 4.24^{\mathrm{aA}}$ \\
7. gün & $10.00 \pm 5.66^{\mathrm{aA}}$ & $11.50 \pm 3.54^{\mathrm{aA}}$ & $11.07^{\mathrm{aA}}$ & $7.39 \pm 2.74^{\mathrm{aA}}$ & $7.80 \pm 1.69^{\mathrm{aA}}$ \\
Renk & $7.72 \pm 2.12^{\mathrm{aA}}$ & $8.36 \pm 1.99^{\mathrm{aA}}$ & $8.24 \pm 1.67^{\mathrm{aA}}$ & $7.30 \pm 1.24^{\mathrm{aA}}$ & $7.89 \pm 1.43^{\mathrm{aA}}$ \\
1. gün & $7.83 \pm 1.39^{\mathrm{aA}}$ & $7.53 \pm 2.16^{\mathrm{aA}}$ & $7.73 \pm 1.74^{\mathrm{aA}}$ & $7.40 \pm 05)$
\end{tabular}

*:Küçük harfler örnekler arası, büyük harfler aynı örneğe ait dönemler arası farklılığı ( $\mathrm{P}<0.05)$ göstermektedir.

Bir sıvının iç sürtünmesi olarak tanımlanan viskozite; ayran kalitesinde etkili olan en önemli stabilite parametrelerinden biridir. En yüksek viskozite değerine depolamanın 1. gününde Kontrol içeceği (4.90 cP); en düşük viskozite değerine ise depolamanın 7. gününde $\mathrm{B}$ ve $\mathrm{C}$ içecekleri $(3 \mathrm{cP})$ sahip olmuştur. Peyniraltı suyu miktarı ile ürünlerin viskozitesi arasında düzensiz bir değişim gözlenmiştir. Pek çok araştırmacı, viskozite üzerine toplam kuru madde, protein ve yağ içeriği, 1sıl işlem ve serum proteinlerinin denatürasyonu, homojenizasyon, asitlik, ürünün depolama sıcaklığı, sütün tuz dengesi, starter kültürün aktivitesi gibi faktörlerin etkili olduğunu bildirmişlerdir (Özünlü ve Koçak 2010). İçeceklerin depolama süresince viskozite değerlerindeki değişim istatistiki olarak önemsiz bulunmuştur ( $>0.05)$. Transglutaminaz enzimi ile süt proteinlerinin enzimatik modifikasyonunun ayran üretiminde uygulanabilirliği ve enzim ilavesinin ürünün kalite kriterleri üzerine etkilerinin araştırıldığı çalışmada; enzim süte üretimin iki farklı aşamasında (pastörizasyondan sonra inkübasyondan önce, starter kültür ile aynı anda) katılmış ve enzimle iki farklı muamale süresi $\left(50^{\circ} \mathrm{C}^{\prime}\right.$ de 1 saat ve $50^{\circ} \mathrm{C}$ 'de 10 dakika) uygulanmıştır. $4^{\circ} \mathrm{C}^{\prime}$ de 20 gün boyunca depolanan ürünlerin depolamanın 1., 10. ve 20. günlerinde yapılan analizlerde örneklerin viskozite değerleri 15 ile $35 \mathrm{cP}$ arasında bulunmuştur (Şanlı ve ark., 2011).

Fermente süt içeceklerinin reolojik özelliklerini yansıtan ve tüketici beğenisi açısından da önemli bir parametre olan serum ayılması değerleri $2 \mathrm{ml}$ ile $10 \mathrm{ml}$ arasında değişiklik göstermiştir. Farklı inkübasyon sonu asitliğin $(4.0,4.3,4.6 \mathrm{pH})$ ayran kalitesi üzerine etkisinin araştırıldığ çalışmada, örneklerin serum ayrılması değerleri (100 ml'lik mezürde, ml cinsinden) 0.0-26.17 arasında bulunmuştur. 14 günlük depolama süresinde örneklerin inkübasyon çıkış pH'ları düştükçe serum ayrılması değerlerinin azaldığı görülmüştür. İstatistiksel değerlendirmeler sonucunda örneklerin farklı pH’larda inkübasyondan çıkarılmasının serum ayrılması üzerine etkisinin önemli olduğu belirlenmiştir (Özünlü ve Koçak, 2010).

Renk değişimini etkileyecek herhangi bir faktör bulunmadığından $L, a, b$ değerleri cinsinden ölçülen renk değerlerinin depolama süresince değişimi istatistiki olarak önemsiz bulunmuştur (p>0.05). Burucu (2008)'nun ayran üretiminde peyniraltı suyu tozu ve kappakaragenan kullanımının örneklerin duyusal, fiziko-kimyasal ve probiyotik özellikleri üzerine etkisini araştırdığı çalışmasında; örneklerin $L^{*}, a^{*}$ ve $b^{*}$ değerleri kullanılan katk1 maddelerinden önemli derecede etkilenmiştir. Peyniraltı suyu protein tozunun artan oranlarda kullanımı $L^{*}$ değerini düşürürken, $a^{*}$ değeri açısından fark oluşturmamış, $b^{*}$ değerini arttırmıştır. Peyniraltı suyuyla zenginleştirilmiş fermente süt içeceğinin duyusal değerlendirme sonucu görünüş, yapı-kıvam, tat-aroma, koku ve genel değerlendirme olmak üzere 5 farklı ölçütte değerlendirilmiş, elde edilen duyusal puanlar ve depolama süresince üründe meydana gelen değişiklikler standart sapmasıyla birlikte verilmiştir. $\% 40$ oranında peyniraltı suyu içeren D içeceği depolamanın hem birinci hem de yedinci gününde en yüksek puanı (7.18-7.56) almıştır. En düşük değeri ise depolamanın 1. gününde $C$ içeceği (6.9) almıştır. Depolama süresince 
bütün içeceklerin görünüş değerleri artış göstermiştir. Yapılan istatiksel analizlerde görünüş değerlerinin depolama süresince değişimi önemsiz bulunmuştur ( $\mathrm{p}>0.05)$.

Yapılan duyusal analizlerde en düşük yapı-kıvam değerini depolamanın 1. gününde $\mathrm{C}$ içeceği (4.8), en yüksek değerini ise depolamanın 7. gününde B içeceği (6.8) almıştır. Depolama süresi sonunda yapı-kıvam değerlerinin artmasında soğukta bekletmenin etkili olduğu düşünülmektedir. Bütün içeceklerin yapı-kıvam değerleri depolama süresi boyunca artış gösterse de bu durum istatiksel açıdan önemsiz bulunmuştur ( $\mathrm{p}>0.05$ ).

En düşük tat değeri depolamanın 1. gününde $\mathrm{C}$ içeceği (4.8), en yüksek değeri ise depolamanın 7. gününde D içeceği (7.4) almıştır. Depolama süresince A içeceği hariç diğer içeceklerin tat-aroma değerleri artış göstermiştir. Probiyotik ayran üretimi üzerine yapılan bir çalışmada, normal ayran kültürlerinin yanında farklı probiyotik kültürler kullanılarak üretilen ürünlerin fiziksel, kimyasal, mikrobiyolojik ve duyusal özellikleri incelenmiştir. Peyniraltı suyu ile zenginleştirilmiş fermente süt içeceklerine ait duyusal analiz sonuçları "Çizelge 6." da gösterilmiştir.

Çizelge 6. Peyniraltı suyuyla zenginleştirilmiş fermente süt içeceklerinin duyusal analiz sonuçları

\begin{tabular}{|c|c|c|c|c|c|}
\hline İçecekler & Kontrol & $\bar{A}$ & $\mathrm{~B}$ & $\bar{C}$ & $\bar{D}$ \\
\hline $\begin{array}{l}\text { Görünüş } \\
\text { 1. gün }\end{array}$ & $7.17 \pm 2.55^{\mathrm{aA}}$ & $6.94 \pm 2.72^{\mathrm{aA}}$ & $7.08 \pm 2.39^{\mathrm{aA}}$ & $6.91 \pm 2.46^{\mathrm{aA}}$ & $7.18 \pm 2.55^{\mathrm{aA}}$ \\
\hline 7. gün & $7.37 \pm 1.81^{\mathrm{aA}}$ & $7.43 \pm 1.77^{\mathrm{aA}}$ & $7.24 \pm 1.90^{\mathrm{aA}}$ & $7.24 \pm 1.90^{\mathrm{aA}}$ & $7.56 \pm 1.66^{\mathrm{aA}}$ \\
\hline $\begin{array}{l}\text { Yap1-k1vam } \\
\text { 1. gün }\end{array}$ & $5.87 \pm 2.43^{\mathrm{aA}}$ & $5.79 \pm 2.65^{\mathrm{aA}}$ & $5.58 \pm 3.35^{\mathrm{aA}}$ & $4.87 \pm 3.22^{\mathrm{aA}}$ & $5.63 \pm 2.89^{\mathrm{aA}}$ \\
\hline 7. gün & $6.81 \pm 2.04^{\mathrm{aA}}$ & $6.32 \pm 2.06^{\mathrm{aA}}$ & $6.89 \pm 1.84^{\mathrm{aA}}$ & $6.44 \pm 2.11^{\mathrm{aA}}$ & $6.72 \pm 1.82^{\mathrm{aA}}$ \\
\hline $\begin{array}{l}\text { Tat-aroma } \\
\text { 1. gün }\end{array}$ & $5.04 \pm 1.75^{\mathrm{aA}}$ & $6.80 \pm 2.02^{\mathrm{aA}}$ & $5.40 \pm 2.23^{\mathrm{aA}}$ & $4.86 \pm 2.99^{\mathrm{aA}}$ & $5.40 \pm 2.51^{\mathrm{aA}}$ \\
\hline 7. gün & $5.36 \pm 3.25^{\mathrm{aA}}$ & $6.23 \pm 1.55^{\mathrm{aA}}$ & $6.61 \pm 2.06^{\mathrm{aA}}$ & $6.04 \pm 3.12^{\mathrm{aA}}$ & $7.44 \pm 1.88^{\mathrm{aA}}$ \\
\hline $\begin{array}{l}\text { Koku } \\
\text { 1. gün }\end{array}$ & $7.10 \pm 2.44^{\mathrm{aA}}$ & $7.94 \pm 1.91^{\mathrm{aA}}$ & $6.17 \pm 3.03^{\mathrm{aA}}$ & $6.72 \pm 3.01^{\mathrm{aA}}$ & $6.97 \pm 2.42^{\mathrm{aA}}$ \\
\hline $\begin{array}{l}\text { 7. gün } \\
\text { Genel }\end{array}$ & $7.16 \pm 2.54^{\mathrm{aA}}$ & $6.91 \pm 1.95^{\mathrm{aA}}$ & $7.53 \pm 1.75^{\mathrm{aA}}$ & $6.68 \pm 2.48^{\mathrm{aA}}$ & $7.54 \pm 1.45^{\mathrm{aA}}$ \\
\hline $\begin{array}{l}\text { Değerlendirme } \\
\text { 1. gün }\end{array}$ & $5.96 \pm 1.62^{\mathrm{aA}}$ & $7.50 \pm 1.65^{\mathrm{aA}}$ & $6.30 \pm 2.12^{\mathrm{aA}}$ & $5.70 \pm 2.78^{\mathrm{aA}}$ & $6.27 \pm 2.44^{\mathrm{aA}}$ \\
\hline 7. gün & $6.16 \pm 2.86^{\mathrm{aA}}$ & $6.20 \pm 1.63^{\mathrm{aA}}$ & $7.13 \pm 1.94^{\mathrm{aA}}$ & $6.43 \pm 2.54^{\mathrm{aA}}$ & $8.07 \pm 1.61^{\mathrm{aA}}$ \\
\hline
\end{tabular}

10 günlük depolama süresinde farklı kültür kullanımının ürünün özellikleri üzerinde meydana getirdiği değişiklikler değerlendirilmiştir. Yapılan duyusal analizlerde probiyotik ayranların tat-aroma değerlerinin normal ayrana göre daha iyi bulunduğu görülmüştür (Tonguç, 2006).

En düşük değeri depolamanın 1. gününde $\mathrm{B}$ içeceği (6.1), en yüksek değeri ise yine depolamanın 1. gününde A içeceği (7.9) almıştır. İçeceklerin koku değerleri depolama süresi boyunca farklı değişimler göstermiştir. Kontrol, B ve D içeceklerinin değerleri artarken; A ve C içeceklerininki azalış göstermiştir. Yoğurt ve sütün sulandırılması ile üretilen ayranların özelliklerinin belirlendiği çalışmada, ayran örneklerine $\% 0.75, \% 1$ ve $\% 1.25$ oranında tuz ilave edilmiştir. Yapılan duyusal analizlerde yoğurdun sulandırıldığ 1 ve $\% 0.75$ ile $\% 1$ oranında tuz içeren örneklerin koku değerleri diğerlerine göre daha yüksek bulunmuştur (Kohneshahri, 2013).

Yapılan duyusal analizlerde genel değerlendirme yönünden en düşük değeri depolamanın 1 . gününde C içeceği (5.7), en yüksek değeri ise depolamanın 7. gününde $D$ içeceği (8.06) almıştır. İçeceklerin genel değerlendirme değerleri depolama süresince farklı değişimler göstermiştir. Kontrol, $\mathrm{B}, \mathrm{C}$ ve $\mathrm{D}$ içeceklerinin değerleri artarken; A içeceğininki azalış göstermiştir.

Görünüş, tat-aroma ve genel değerlendirme yönünden en yüksek puanı $\% 40$ oranında peyniraltı suyu içeren D içeceğinin almış olması, yapı-kıvam ve koku değerlerinin ise ortalamanın üstünde seyretmesi çalışmamızın uygulanabilirliği açısından önemli bir sonuçtur. Çünkü hem tüketicinin beğeneceği bir ürün elde etmek, hem de yüksek oranda peyniraltı suyu kullanarak çevreye bırakılan ve önemli bir besin kaynağı olan peyniraltı suyundan faydalanmak araştırmamızın esasını oluşturmaktadır. 


\section{Tartışma ve Sonuç}

Türkiye'de sevilerek fazla miktarda tüketilen fermente süt içeceklerinin başında ayran gelmektedir. Türk damak tadına uygun olarak peyniraltı suyu katılmasıyla ayran benzeri böyle bir fermente süt içeceğinin üretilmesi atık bir ürünün değerlendirilmesine imkan vermesinin yanı sıra ürüne fonksiyonellik katarak uygun yeni bir fermente süt içeceği üretilmesini sağlamaktadır. Yeni neslin gazlı içecek sanayine artan talepleri, bu şekilde daha fonksiyonel, sağlıklı ve besleyici ürünler üretilerek uygun gıdalara yönlendirilmiş olacaktır.

Bu çalışmada farklı oranlarda peyniraltı suyu kullanılarak fermente süt içecekleri üretilmiştir. Üretilen içeceklerin depolama süresi 20 gün öngörülmüş ancak kontrol grubunun depolamanın 7. gününden sonra bozulmaya başlamasıyla çalışma sonlandırılmıştır. Depolamanın 1. ve 7. günlerinde içecekler fiziksel, kimyasal, duyusal ve istatistiksel analizlere tabi tutulmuştur. Çalışma süresince yapılan analizler ışı̆̆ında aşağıdaki sonuçlar elde edilmiştir;

1. İçeceklerin kuru madde, kül, yağ ve protein değerleri literatürdeki benzer ürünlere göre düşük çıkmıştır. Bunun sebebi; fermente süt içeceği üretilirken kullanılan hammaddenin kuru madde, yağ ve protein oranının düşüklüğüdür.

2. Fermente süt içeceklerinin önemli reolojik özelliklerini yansıtan değerlerden biri olan serum ayrılması değeri yüksek bulunmuştur. Bu durum düşük kuru maddeli hammadde kullanımından, katılan peyniraltı suyunun da etkisiyle asitliğin hızlı bir şekilde oluşmasından ve depolama koşullarından kaynaklanabilmektedir.

3. Üretilen içeceklerin raf ömürleri market ürünlerine göre kısa süreli olmuştur. Bu nedenle de daha sonra yapılacak çalışmalarda aseptik ambalajlamadan sonra pastörizasyon/sterilizasyon sıcaklık/süre kombinasyonları daha iyi ayarlanmalıdır. Ayrıca yapılan analizlere ek olarak mikrobiyolojik analizleri de yapılmalıdır.

Yurt dışında peyniraltı suyundan üretilen birçok içecek mevcut iken ülkemizde üretilen peyniraltı suyu bir atık olarak görülmektedir. Çalışmanın esas amacını da atık olarak zengin besin içeriğine sahip bir üründen olabildiğince ekonomik şekilde faydalanmak oluşturmaktadır.

Bu çalışma ile Türkiye'de üretilebilecek yeni fermente süt içeceklerine 1şık tutulmuş olmakta, peyniraltı suyu gibi kıymetli bir ürünün herhangi ek bir masrafa gerek kalmadan direkt olarak bu sanayinin gelişiminde rahatlıkla kullanılabileceği gösterilmektedir. Özellikle duyusal analizlerde en yüksek oranda $(\% 40)$ peyniraltı suyu içeren D içeceğinin yüksek puan almış olması, böylelikle ürünlerin üretiminde daha fazla peyniraltı suyunun kullanılması peyniraltı suyunun değerlendirilmesi açısından sevindirici bir durumdur. Bundan sonraki çalışmalarda, özellikle kaliteli protein alması gereken yaşlı insanlar, gelişme yaşındaki çocuklar ve günlük süt/süt ürünleri tüketimi yetersiz yetişkinler için yapılacak düzenlemelerle içecek formülasyonu geliştirilebileceği, doğal aromalar eklenebileceği ve daha yeni ürünler geliştirilebileceği düşünülmektedir.

\section{Kaynakça}

Alpkent, Z., \& Göncü, A.(2003). Peynir suyu ve peynir suyu proteinlerinin gida, kozmetik ve tıp alanlarında kullanımı. Akdeniz Üniversitesi Glda Mühendisliği Dergisi, 26-30.

AOAC. (1990). Official Methods of Analysis (15th Ed.). Washington, DC: Association Official Analysis Chemists.

Bakırc1, İ., \& Kavaz, A., (2006, Mayıs). Peyniraltı suyunun değerlendirilme olanakları. Türkiye 9. Gida Kongresi, Bolu.

Balcığlu, H. (2013). Askorbik asit ve çilek ilavesinin probiyotik fermente süt içeceğinin bazı özellikleri üzerine etkileri. Harran Üniversitesi, Fen Bilimleri Enstitüsü Yüksek Lisans Tezi Urfa, Türkiye.

Burucu, H. (2008). Ayran üretiminde peyniraltı suyu ürünleri ile kappakarragenan kullanıminın duyusal-fizikokimyasal ve probiyotik özellikler üzerine etkisi. Selçuk Üniversitesi, Fen Bilimleri Enstitüsü Yüksek Lisans Tezi Konya, Türkiye.

Dağl1, A. (2006). Yoğurt dondurması üretiminde peyniraltı suyu tozu kullanımı. Ankara Üniversitesi, Fen Bilimleri Enstitüsü Doktora Tezi Ankara, Türkiye.

Dinçoğlu, A,. \& Ardıç, M. (2012). Peyniraltı suyunun beslenmemizdeki önemi ve kullanım olanakları. Harran Üniversitesi Veterinerlik Fakültesi Dergisi, 1, 54-60. 
Doğan, S. (2002). Bisküvi üretiminde kalite kriteri olarak renk ölçümüne yeni bir yaklaşım. Türkiye 7. G1da Kongresi, Ankara.

Esmek, M. (2014). Kefir kültürü kullanılarak üretilen peyniraltı sulu içeceğin bazı özellikleri ve depolama süresinin etkisi. Çukurova Üniversitesi, Fen Bilimleri Enstitüsü Yüksek Lisans Tezi Adana, Türkiye.

Ferliarslan, İ. (2013). Farklı oranlarda yulaf lifi ve inülin ilavesinin kayısıl probiyotik fermente süt içeceğinin bazı özelliklerine etkileri. Harran Üniversitesi, Fen Bilimleri Enstitüsü Yüksek Lisans Tezi Urfa, Türkiye.

Holsinger, H., Posati, P., \& DeVilbiss, D. (1974). Whey beverages: A Review. Journal of Dairy Science, 57(8), 849-859.

Jeličić, I., Božanić, R., \& Tratnik, L. (2008). Whey based beverages-a new generations of dairy products. Mljekanrstvo, 58(3),257-274.

Karagözlü, C., \& Bayarer, M. (2004). Peyniraltı suyu proteinlerinin fonksiyonel özellikleri ve sağlık üzerine etkileri. Ege Üniversitesi Ziraat Fakültesi Dergisi, 41(2), 197-207.

Kırdar, S. (2001). Peyniraltı suyu içecekleri. S.D.Ü. Fen Bilimleri Enstitüsü Dergisi, 5(2), 154-164.

Kohneshahri, S. (2013). Yoğurt ve sütün sulandırılması ile üretilen ayranların özellikleri. Atatürk Üniversitesi, Fen Bilimleri Enstitüsü Yüksek Lisans Tezi Erzurum, Türkiye.

Kosikowski, F. (1968). Nutrional beverages from acid whey powder. J. Dairy Sci., 51(8), 1299-1301.

Köksoy, A., \& Kılıc, M. (2004). Use of hydrocolloids in textural stabilization of a yoghurt drink ayran. Food hydrocolloids,18(4), 593-600.

Kurt, A., Çakmakçı, S., \& Çağlar, A. (2003). Süt Mamülleri Muayene ve Analiz Metotlar Rehberi (284). 8. Bask1. Atatürk Üniversitesi Yayınları. Yay. No: 252-D.

Öğünç, A., \& Yalçın, S. (2011). Süt serumu proteinlerinin in vitro koşullardaki antioksidan etkileri. Marmara Eczacllik Dergisi, 15, 18-24.

Özaltın, E. (2011). Yağslz süte katılan peyniraltı suyunun, civil peynirin bazı fiziksel, kimyasal ve mikrobiyolojik kalitesi üzerine etkisi. Atatürk Üniversitesi, Fen Bilimleri Enstitüsü Yüksek Lisans Tezi Erzurum, Türkiye.

Özcan, T., \& Delikanlı, B. (2011). Gıdaların tekstürel özelliklerinin geliştirilmesinde peyniraltı suyu protein katkılarının fonksiyonel etkileri. Uludağ Üniversitesi Ziraat Fakültesi Dergisi, 25(2), 77-78.

Özünlü, B., \& Koçak, C. (2010). Süte farklı ısıl işlem uygulamalarının ayran kalitesine etkisi. Ankara Üniversitesi Süt Teknolojisi Dergisi, 35(5), 355-362.

SPSS. (1998). SPSS for Windows Base System User's Quide Release 9.00.Chicago IL, USA.

Şen, İ. (2015). Kefir kültürü kullanılarak üretilen fermente süt ürünlerinin aroma aktif bileşenlerinin ve duyusal özelliklerinin belirlenmesi. Onsekiz Mart Ünivesitesi, Fen Bilimleri Enstitüsü Yüksek Lisans Tezi Çanakkale, Türkiye.

Tonguç, İE. (2006). Probiyotik ayran üretimi üzerine bir araştırma. Ege Üniversitesi, Fen Bilimleri Enstitüsü Yüksek Lisans Tezi İzmir, Türkiye.

Yerlikaya, O., Kınık, Ö., \& Akbulut, N. (2010). Peyniraltı suyunun fonksiyonel özellikleri ve peyniraltı suyu kullanılarak üretilen yeni nesil süt ürünleri. Gıda Dergisi, 35(4), 289-296.

Yılmaz, L. (2006). Yoğurt benzeri fermente süt ürünleri üretiminde farklı probiyotik kültür kullanımlarının kullanımı. Uludağ Üniversitesi, Fen Bilimleri Enstitüsü Doktora Tezi Bursa, Türkiye. 